\title{
The Level of Stress among the College going Adolescents Living in Guwahati City of Assam
}

\author{
Smita Sharma ${ }^{1} *$
}

\section{ABSTRACT}

Stress is a part of life and every one experiences it in everyday life affair. Adolescents are very often confronted with stress. The objectives of the study are to find out the level of stress among adolescent boys and girls living in Guwahati City of Assam. Another objective is to find out the level of stress of pressure, physical stress, anxiety and frustration among adolescent boys and girls living in Guwahati City of Assam. Descriptive method is used in the study. The sample of 214 adolescents of Guwahati city was selected purposively for the study. The findings of the study reveal that most of the adolescents have moderate level of stress.

Keywords: Stress, Adolescence and Guwahati City

Development is a continuous process which starts from birth and ends with the death. Development encompasses various stages of an individual starting from infancy till old age. Adolescence is one of the stages of development. It is the period in the life span when both the immediate effects and long term effects are important. The term Adolescence is derived from the Latin word "adolescere" meaning "to grow" or "to grow to maturity". It is a period that starts with the onset of puberty and extent till the adolescents reaches the age of legal maturity.

Adolescence is a period of change in attitude and behaviour, develops heightened emotionality, outlook, interests pattern and roles the social group expects them to play. This period is regarded as the period of "storm and stress". The adolescents are very often confronted with stress in their day to day life. It may be due to self, career, academics or other issues. As a consequence the adolescents undergo anxiety, physical stress, aggression, undesirable complexes and depression. Stress is the key factor affecting the mental health of adolescents. This provides a major reason for conducting a study on the stress level of adolescents. This will assist the educators, social thinkers, psychologist and scholars to provide measures and methods to remove stress. Proper

\footnotetext{
${ }^{1}$ M.Phil Student, Department of Education, Dibrugarh University, India

*Responding Author

(C) 2016, S Sharma; licensee IJIP. This is an Open Access Research distributed under the terms of the Creative Commons Attribution License (http://creativecommons.org/licenses/by/2.0), which permits unrestricted use, distribution, and reproduction in any Medium, provided the original work is properly cited.
} 
education and guidance is necessary among the adolescents to develop positive attitude and healthy life.

\section{Meaning of stress}

The term "Stress" was first used by the endocrinologist Hans Selye in 1936 to identify physiological responses in laboratory animals. He later broadened and popularized the concept to include the perceptions and responses of human beings trying to adapt challenges of everyday life. He defined stress as "the nonspecific response of the body to any demand."

Stress is an internal state which is caused by physical demands on the body, the environmental and social situations which are potentially harmful, uncontrollable or exceeding our resources for coping life events and pressure of everyday life. Stress is a part of life and every one experiences it. Stress only differs in their level of stress experience and ranges from mild to severe. In the study, four dimension of stress were included. These are given below:-

$\begin{array}{ll}\text { - } & \text { Pressure } \\ \text { - } & \text { Physical Stress } \\ \text { - } & \text { Anxiety } \\ & \text { Frustration }\end{array}$

\section{Concept of Adolescents}

The adolescence is one of the stages of development. It is a period between late childhood and adulthood. It is an important period in one's life span consisting of transitional period, a problem age and period of change, a search for identity, a dreaded age, a time of unrealism and the threshold of adulthood. Adolescents refer to those boys and girls belonging to the adolescence period. In the study, Adolescents are the college going boys and girls in the age group of 19-22 years.

\section{Guwahati City}

Guwahati City is the largest city in North East India. It is the gateway to the Seven Sister States. The old name of Guwahati is Pragjyotispur. It is situated in the southern bank of river Brahmaputra with its cardinal points as $26^{0} 10^{\prime} \mathrm{N}$ latitude and $92^{0} 49^{\prime} \mathrm{E}$ longitude. The total area of Guwahati is $328 \mathrm{sq} \mathrm{km}$. Guwahati is the largest commercial, industrial and educational hub in the North East.

\section{Rationale of the Study}

The rationales for undertaking the study are reproduced below:-

- $\quad$ Firstly, Stress is an everyday life affair. Stress among adolescences is very prominent due to self, career, academics or other issues. As a result they undergo anxiety, physical stress, aggression, undesirable complexes and depression. This leads them to engage in illegal and anti 
The Level of Stress among the College going Adolescents Living in Guwahati City of Assam

social activities and act as the key factor affecting their mental health. This provides a major reason for conducting a study on the stress level of adolescents.

- $\quad$ Secondly, a very little study has been conducted among the adolescents of Guwahati City in relation to their level of stress.

\section{Statement of the Problem}

The problem taken for study is stated as "The Level of Stress among the College going Adolescents Living in Guwahati City of Assam"

\section{Research Questions of the Study}

The research questions of the study are:-

1. What is the level of stress among College going adolescents living in Guwahati City of Assam?

2. What is the level of stress of Pressure, Physical Stress, Anxiety and Frustration among College going adolescents living in Guwahati City of Assam?

3. What is the level of stress among the College going adolescents living in Guwahati City of Assam in terms of Gender?

4. What is the level of stress of Pressure, Physical Stress, Anxiety and Frustration among the College going adolescents living in Guwahati City of Assam in terms of Gender?

\section{Objectives of the Study}

The objectives of the study are as follows:-

- To find out the level of stress among the College going adolescents living in Guwahati City of Assam.

- To find out the level of stress of Pressure, Physical Stress, Anxiety and Frustration among the College going adolescents living in Guwahati City of Assam.

- To study the level of stress among the College going adolescents living in Guwahati City of Assam in terms of Gender.

- To study the level of stress of Pressure, Physical Stress, Anxiety and Frustration among the College going adolescents living in Guwahati City of Assam in terms of Gender..

- To make a comparative study between the level of stress of College going adolescent boys and girls living in Guwahati City of Assam.

\section{Hypothesis of the Study}

The hypothesis of the study is:

1. There exists no significant difference between the level of stress of the College going adolescent boys and girls living in Guwahati City of Assam.

(c) The International Journal of Indian Psychology, ISSN 2348-5396 (e)| ISSN: 2349-3429 (p) | 193 
The Level of Stress among the College going Adolescents Living in Guwahati City of Assam

\section{Delimitation of the Study}

The study is delimited under the following aspects:-

- The study is delimited to Panbazar and Lokhara area of Guwahati city of Assam.

- In the study, the adolescents refer to the college going boys and girls in the age group of 1922.

\section{REVIEW OF RELATED LITERATURE}

The researcher had studied certain literature related to the problem of investigation. Devi (2011) conducted a study on "A Study on Stress Management and Coping Strategies with reference to IT Companies". The paper throws light on the wide spread silent problem by the name 'Stress', which gives rise to acute dysfunctions and many diseases, increased divorce rates and other harassments. Another study was conducted by Hussain (2010) on "A Study of Teacher Stress: Exploring Practitioner Research and Teacher Collaboration as a way forward". The study centers around the issues relating to teacher stress which includes the way in which teacher stress is being measured and the effectiveness of qualitative over quantitative methods, the inclusion and exclusion practices of disruptive students and the use of practitioner research to encourage teacher collaborative as a way of dealing with teacher stress. Mazumdar, Gogoi and Haloi (2012) conducted a study on "A Comparative study on Stress and its Contributing factors among the Graduates and Post Graduates Students". The paper focuses on the symptoms of stress and its difference between male and female. Wen studied on "A Study of Stress sources among college students in Taiwan". The study investigates the sources of stress among college students in Taiwan. It was found that male students feel stronger stress from family factor then female. Education International (EI) European Trade Union Committee for Education (ETUCE) in collaboration with the WHO conducted a study on stress. It studied the causes of stress for teachers, its effects and suggested approaches to reduce it.

\section{METHODOLOGY}

The research method used in the study is the Descriptive Method. This method was selected on the basis of the nature of the study. This study is mainly concern with the present state of level of stress among the adolescents of Guwahati City.

\section{Population of the Study}

The population of the study is all the college going adolescents in the age group of 19-22 years living in the Panbazar and Lokhara area of Guwahati city of Assam.

\section{Sample of the Study}

Sample is the representative proportion of the population. The sampling method used was purposive sampling technique. The sample size includes 214 adolescents in the age group of 1922 years of age. 
The Level of Stress among the College going Adolescents Living in Guwahati City of Assam

\section{Tool Used In the Study}

The tool used in the study was the Stress Scale developed by Dr. (Mrs.) Vijaya Lakshmi and Dr.

Shruti Narain.

\section{RESULT AND DISCUSSION}

Analysis and Interpretation

OBJECTIVE NO: 1

Table 1.1, Level of Stress among the College going Adolescents

\begin{tabular}{|l|l|l|l|}
\hline Sl. No. & Level of Stress & Number of Adolescent & Percentage \\
\hline 1 & High (28-40 scores) & 6 & $2.81 \%$ \\
\hline 2 & Moderate (14-27 Scores) & 142 & $66.35 \%$ \\
\hline 3 & Low (0-13 scores) & 66 & $30.84 \%$ \\
\hline Total & & 214 & $100 \%$ \\
\hline
\end{tabular}

The above Table shows that the level of stress among the college going adolescents is moderate (66.35\%), followed by Low (30.84\%) and High (2.81\%).

The graphical representation of the above data has shown as follows-

\section{Level of Stress among the College going Adolescents}

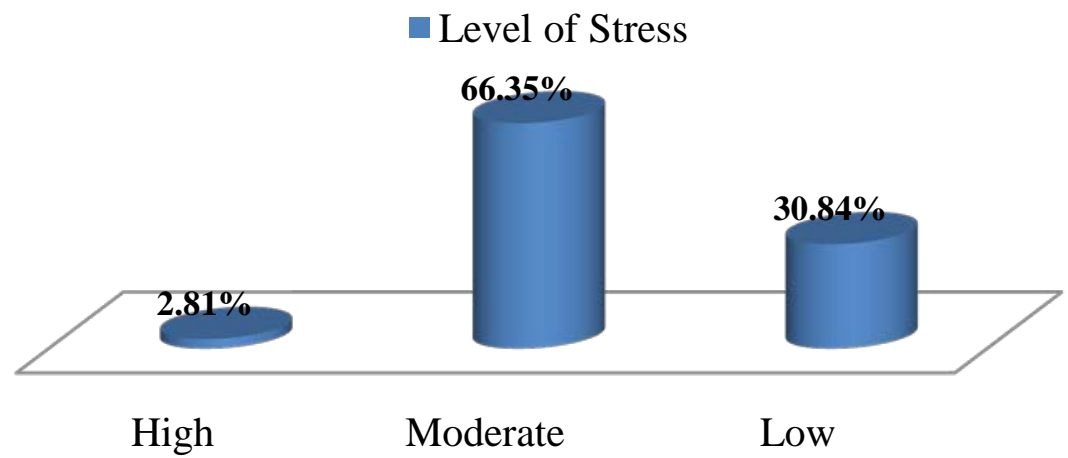

Figure 1.1- Level of Stress among College going Adolescents

OBJECTIVE NO: 2

Table 2.1, Level of Stress of Pressure among the College going Adolescents

\begin{tabular}{|l|l|l|l|}
\hline Sl. No. & Level of Stress of Pressure & Number of Adolescent & Percentage \\
\hline 1 & High (10-14 scores) & 8 & $3.74 \%$ \\
\hline 2 & Moderate (5-9 Scores) & 140 & $65.42 \%$ \\
\hline 3 & Low (0-4 scores) & 66 & $30.84 \%$ \\
\hline Total & 214 & $100 \%$ \\
\hline
\end{tabular}

(c) The International Journal of Indian Psychology, ISSN 2348-5396 (e)| ISSN: 2349-3429 (p) | 195 
The Level of Stress among the College going Adolescents Living in Guwahati City of Assam

The Table 2.1 shows that, regarding Pressure the level of stress is high among 3.74\% adolescents, Moderate among 65.42\% and Low among 30.84\% adolescents.

The graphical representation of the above data has shown as follows-

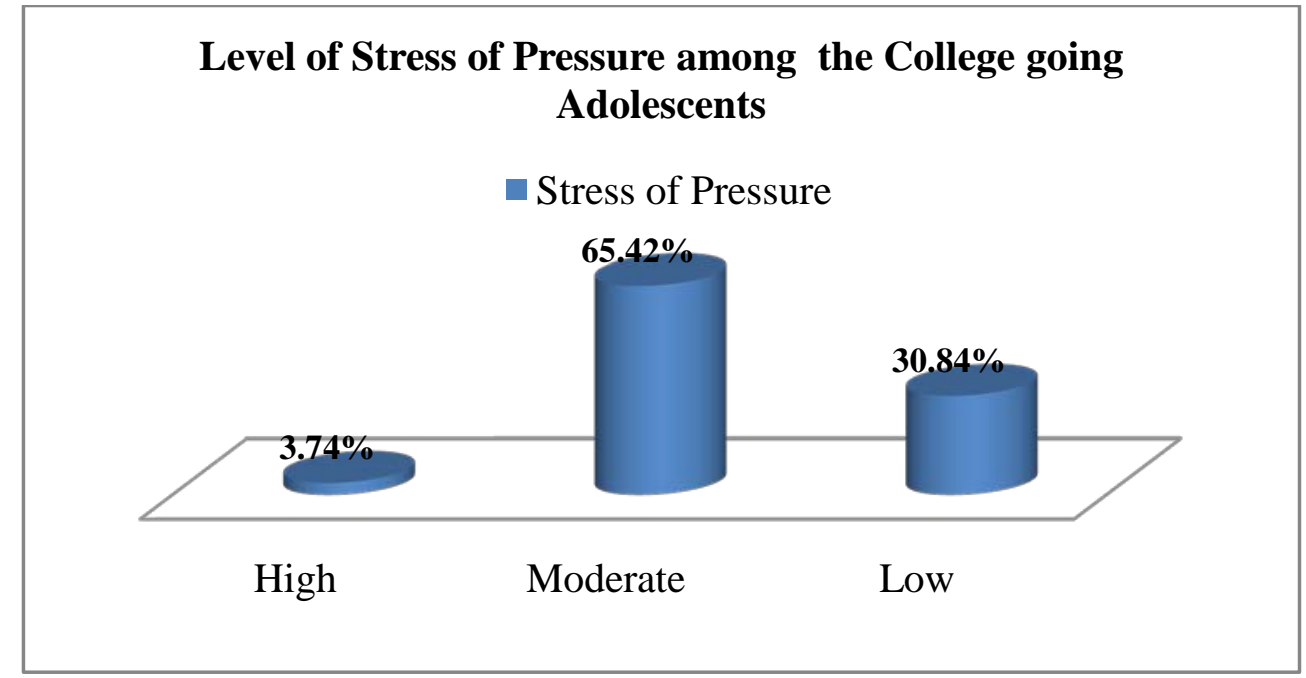

Figure 2.1- Level of Stress of Pressure among the College going Adolescents

Table 2.2, Level of Physical Stress among the College going Adolescents

\begin{tabular}{|l|l|l|l|}
\hline Sl. No. & Level of Physical Stress & Number of Adolescent & Percentage \\
\hline 1 & High (3-4 scores) & 67 & $31.30 \%$ \\
\hline 2 & Moderate (2 Scores) & 72 & $33.65 \%$ \\
\hline 3 & Low (0-1 scores) & 75 & $35.05 \%$ \\
\hline Total & 214 & $100 \%$ \\
\hline
\end{tabular}

Regarding Physical Stress, the above Table shows that 35.05\%, 33.65\% and 31.30\% adolescents have Low, Moderate and High level of Physical Stress respectively.

The graphical representation of the above data has shown as follows-

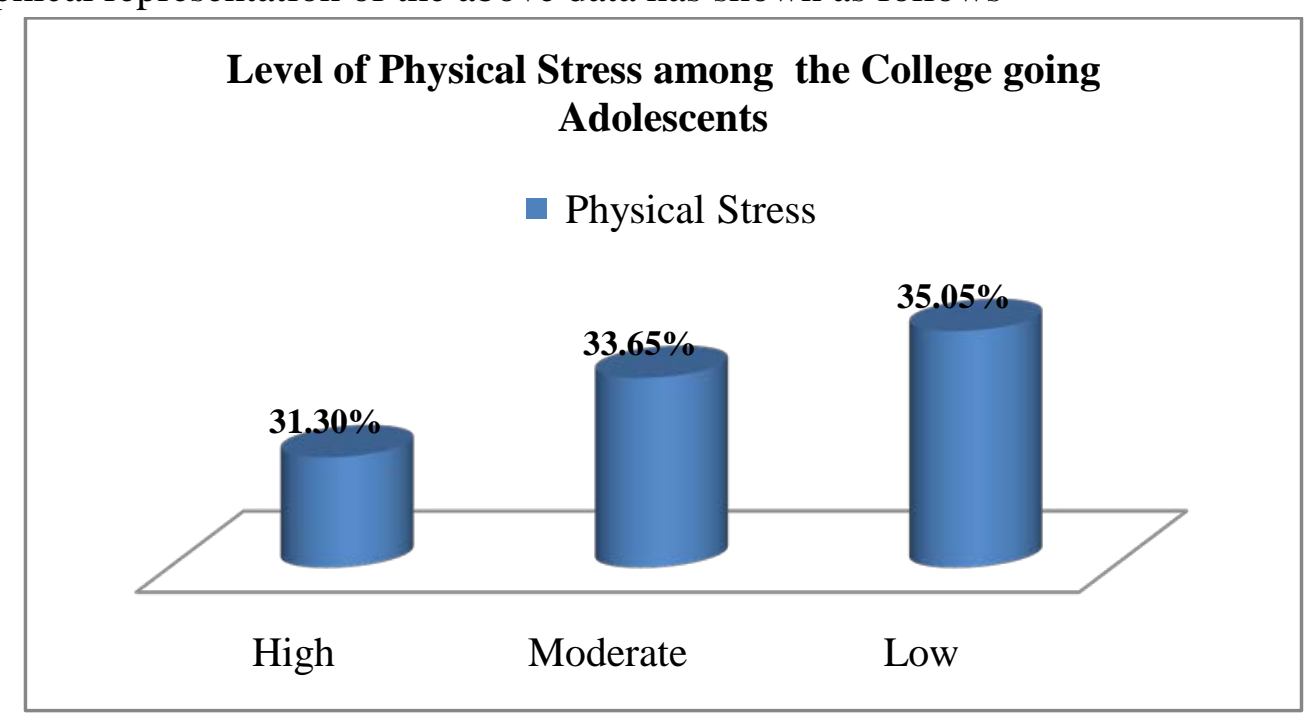

Figure 2.2- Level of Physical Stress among the College going Adolescents

(c) The International Journal of Indian Psychology, ISSN 2348-5396 (e)| ISSN: 2349-3429 (p) | 196 
The Level of Stress among the College going Adolescents Living in Guwahati City of Assam

Table 2.3, Level of Anxiety among the College going Adolescents

\begin{tabular}{|l|l|l|l|}
\hline Sl. No. & Level of Anxiety & Number of Adolescent & Percentage \\
\hline 1 & High (10-13 scores) & 10 & $4.67 \%$ \\
\hline 2 & Moderate (5-9 Scores) & 132 & $61.68 \%$ \\
\hline 3 & Low (0-4 scores) & 72 & $33.65 \%$ \\
\hline Total & 214 & $100 \%$ \\
\hline
\end{tabular}

The Table 2.3 shows that, regarding Anxiety the level of stress is High among 4.67\% adolescents, Moderate among 61.68\% and Low among 33.65\% adolescents.

The graphical representation of the above data has shown as follows-

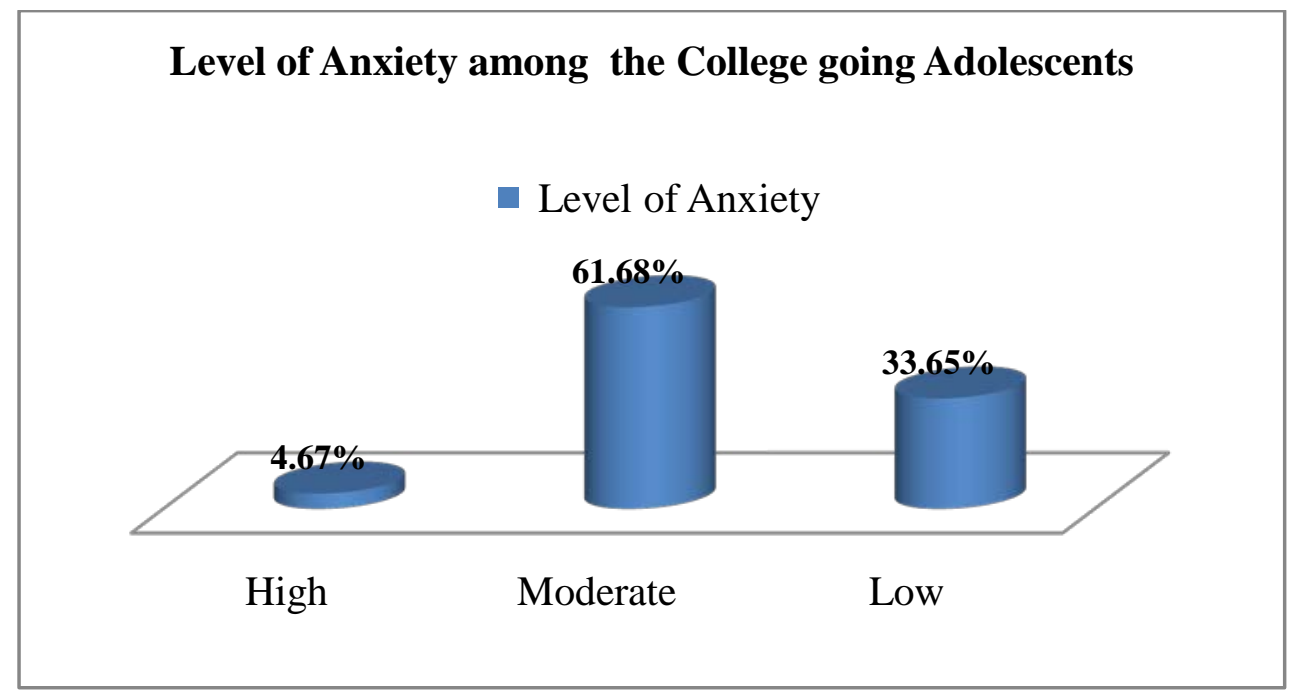

Figure 2.3- Level of Anxiety among the College going Adolescents

Table 2.4, Level of Frustration among College going Adolescents

\begin{tabular}{|l|l|l|l|}
\hline Sl. No. & Level of Frustration & Number of Adolescent & Percentage \\
\hline 1 & High (6-9 scores) & 19 & $8.88 \%$ \\
\hline 2 & Moderate (3-5 Scores) & 67 & $31.31 \%$ \\
\hline 3 & Low (0-2 scores) & 128 & $59.81 \%$ \\
\hline Total & 214 & $100 \%$ \\
\hline
\end{tabular}

Regarding Frustration, the above Table shows that 59.81\%, 31.31\% and 8.88\% adolescents have Low, Moderate and High level of frustration respectively.

(c) The International Journal of Indian Psychology, ISSN 2348-5396 (e)| ISSN: 2349-3429 (p) | 197 
The Level of Stress among the College going Adolescents Living in Guwahati City of Assam

The graphical representation of the above data has shown as follows-

Level of Frustration among the College going

Adolescents

- Frustraion

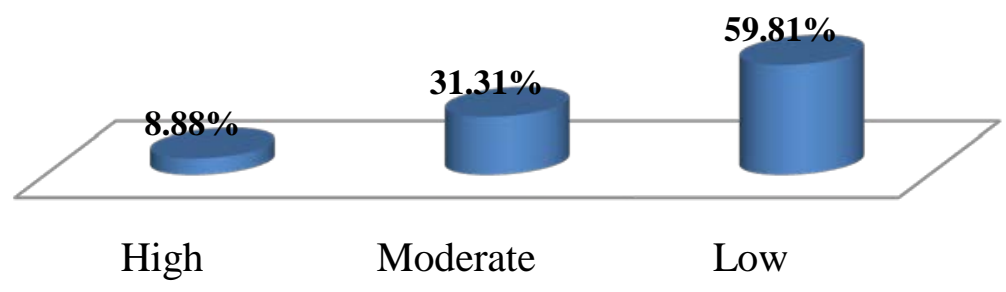

Figure 2.4- Level of Frustration among the College going Adolescents

OBJECTIVE NO: 3

Table 3.1, Level of Stress among the College going Adolescent Boys

\begin{tabular}{|l|l|l|l|}
\hline Sl. No. & Level of Stress & Number of Adolescent & Percentage \\
\hline 1 & High (22 scores and above) & 21 & $19.63 \%$ \\
\hline 2 & Moderate (12-22 Scores) & 72 & $67.29 \%$ \\
\hline 3 & Low (0-11 scores) & 14 & $13.08 \%$ \\
\hline Total & 107 & $100 \%$ \\
\hline
\end{tabular}

Table 3.2, Level of Stress among the College going Adolescent Girls

\begin{tabular}{|l|l|l|l|}
\hline Sl. No. & Level of Stress & Number of Adolescent & Percentage \\
\hline 1 & High (25 scores and above) & 8 & $7.48 \%$ \\
\hline 2 & Moderate (14-24 Scores) & 56 & $52.33 \%$ \\
\hline 3 & Low (0-13 scores) & 43 & $40.19 \%$ \\
\hline Total & 107 & $100 \%$ \\
\hline
\end{tabular}

The above Table 3.1 and Table 3.2 shows that $67.29 \%, 19.63 \%$ and $13.08 \%$ college going adolescent boys have Moderate, High and Low level of stress. Again 52.33\%, 40.19\% and 7.48\% adolescent girls have Moderate, Low and High level of stress.

(c) The International Journal of Indian Psychology, ISSN 2348-5396 (e)| ISSN: 2349-3429 (p) | 198 
The Level of Stress among the College going Adolescents Living in Guwahati City of Assam

The graphical representation of the above data has shown as follows-

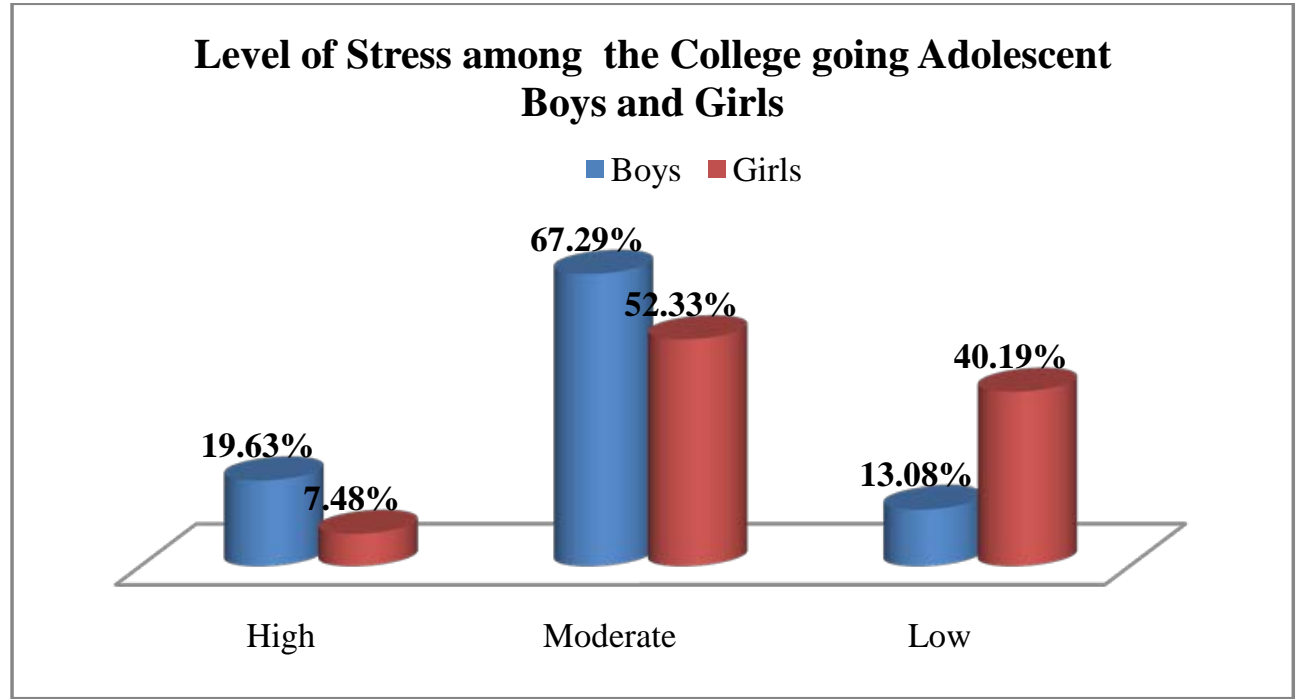

Figure 3.1- Level of Stress among the College going Adolescent Boys and Girls

OBJECTIVE NO: 4

Table 4.1, Level of stress of Pressure among the College going Adolescent Boys

\begin{tabular}{|l|l|l|l|}
\hline Sl. No. & Level of Stress of Pressure & Number of Adolescent & Percentage \\
\hline 1 & High (7 and above) & 54 & $50.46 \%$ \\
\hline 2 & Moderate (3-6 Scores) & 48 & $44.86 \%$ \\
\hline 3 & Low (0-2 scores) & 5 & $4.68 \%$ \\
\hline Total & 107 & $100 \%$ \\
\hline
\end{tabular}

Table 4.2, Level of stress of Pressure among the College going Adolescent Girls

\begin{tabular}{|l|l|l|l|}
\hline Sl. No. & Level of Stress of Pressure & Number of Adolescent & Percentage \\
\hline 1 & High (8 and above) & 16 & $14.96 \%$ \\
\hline 2 & Moderate (4-7 Scores) & 64 & $59.81 \%$ \\
\hline 3 & Low (0-3 scores) & 27 & $25.23 \%$ \\
\hline Total & 107 & $100 \%$ \\
\hline
\end{tabular}

Regarding stress of Pressure the above Table 4.1 and Table 4.2 shows that $50.46 \%$, 44.86\% and 4.68\% adolescent boys have High, Moderate and Low level of Pressure. Again 59.81\%, 25.23\% and 14.96\% adolescent girls have Moderate, Low and High level of Pressure.

(c) The International Journal of Indian Psychology, ISSN 2348-5396 (e)| ISSN: 2349-3429 (p) | 199 
The graphical representation of the above data has shown as follows-

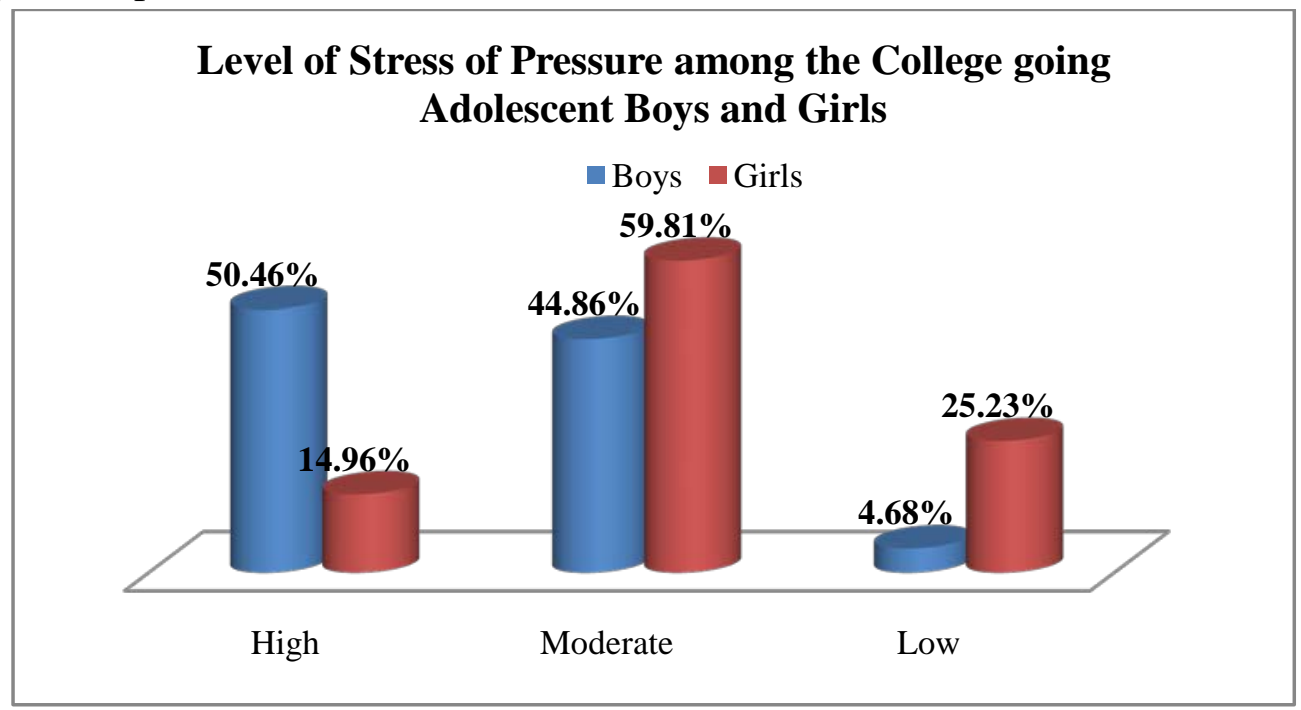

Figure 4.1- Level of Stress of Pressure among the College going Adolescent Boys and Girls

Table 4.3, Level of Physical Stress among the College going Adolescent Boys

\begin{tabular}{|l|l|l|l|}
\hline Sl. No. & Level of Physical Stress & Number of Adolescent & Percentage \\
\hline 1 & High (3 and above) & 37 & $34.57 \%$ \\
\hline 2 & Moderate (2 Score) & 34 & $31.78 \%$ \\
\hline 3 & Low (0-1 scores) & 36 & $33.65 \%$ \\
\hline Total & 107 & $100 \%$ \\
\hline
\end{tabular}

Table 4.4, Level of Physical Stress among the College going Adolescent Girls

\begin{tabular}{|l|l|l|l|}
\hline Sl. No. & Level of Physical Stress & Number of Adolescent & Percentage \\
\hline 1 & High (3 and above) & 30 & $28.03 \%$ \\
\hline 2 & Moderate (2 Score) & 38 & $35.52 \%$ \\
\hline 3 & Low (0-1 scores) & 39 & $36.45 \%$ \\
\hline Total & 107 & $100 \%$ \\
\hline
\end{tabular}

Regarding Physical Stress the above Table 4.3 and Table 4.4 shows that $34.57 \%$, 31.78\% and 33.65\% adolescent boys have High, Moderate and Low level of Physical Stress. On the other hand, 28.03\%, 35.52\% and 36.45\% adolescent girls have High, Moderate and Low level of Physical Stress.

(c) The International Journal of Indian Psychology, ISSN 2348-5396 (e)| ISSN: 2349-3429 (p) | 200 
The graphical representation of the above data has shown as follows-

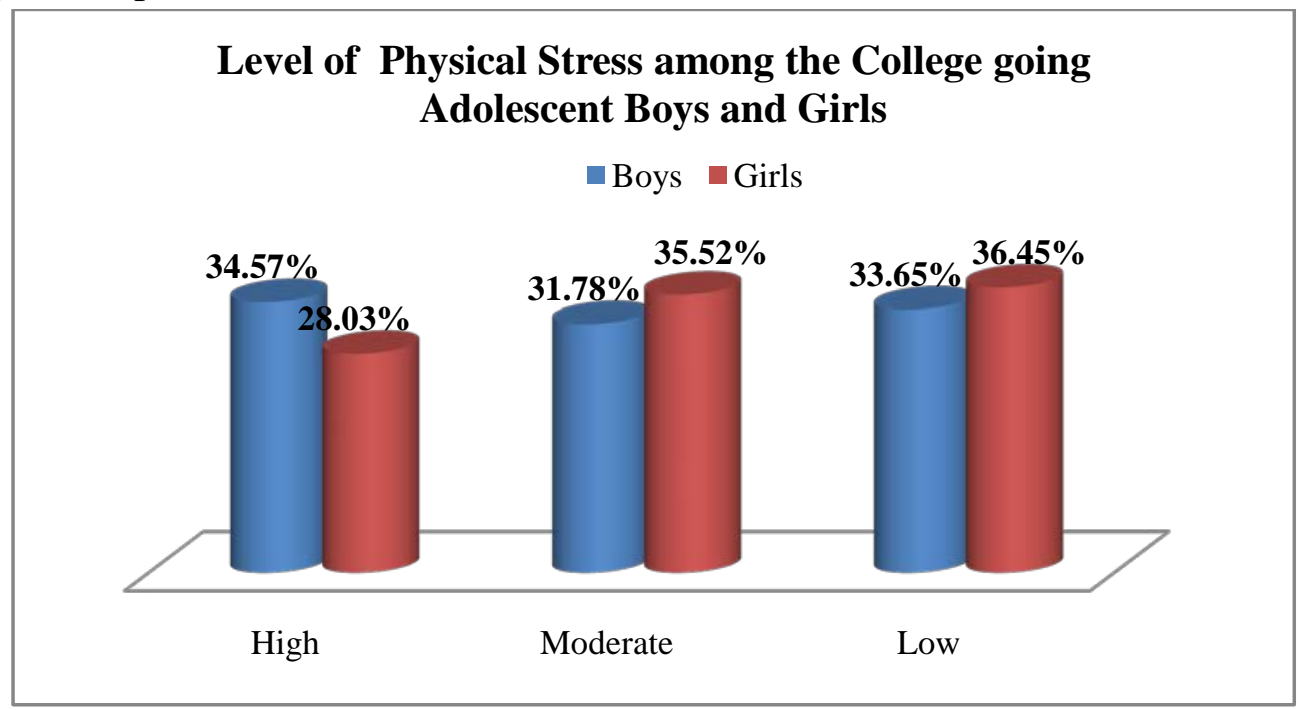

Figure 4.2- Level of Physical Stress among the College going Adolescent Boys and Girls

Table 4.5, Level of Anxiety among the College going Adolescent Boys

\begin{tabular}{|l|l|l|l|}
\hline Sl. No. & Level of Anxiety & Number of Adolescent & Percentage \\
\hline 1 & High (7 and above) & 44 & $41.12 \%$ \\
\hline 2 & Moderate (4-6 Scores) & 41 & $38.32 \%$ \\
\hline 3 & Low (0-3 scores) & 22 & $20.56 \%$ \\
\hline Total & 107 & $100 \%$ \\
\hline
\end{tabular}

Table 4.6, Level of Anxiety among the College going Adolescent Girls

\begin{tabular}{|l|l|l|l|}
\hline Sl. No. & Level of Anxiety & Number of Adolescent & Percentage \\
\hline 1 & High (8 and above) & 26 & $24.30 \%$ \\
\hline 2 & Moderate (4-7 Scores) & 54 & $50.47 \%$ \\
\hline 3 & Low (0-3 scores) & 27 & $25.23 \%$ \\
\hline Total & 107 & $100 \%$ \\
\hline
\end{tabular}

Regarding Anxiety the Table 4.5 and Table 4.6 shows that $41.12 \%, 38.32 \%$ and $20.56 \%$ adolescent boys have High, Moderate and Low level of anxiety. On the other hand, 50.47\%, 25.23\% and 24.30\% adolescent girls have Moderate, Low and High level of anxiety.

(c) The International Journal of Indian Psychology, ISSN 2348-5396 (e)| ISSN: 2349-3429 (p) | 201 
The Level of Stress among the College going Adolescents Living in Guwahati City of Assam

The graphical representation of the above data has shown as follows-

\section{Level of Anxiety among the College going Adolescent \\ Boys and Girls}

Boys Girls

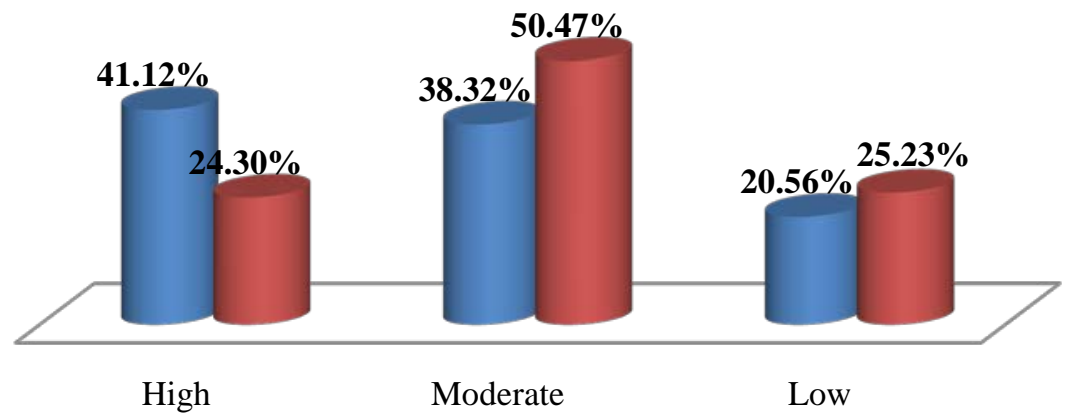

Figure 4.3- Level of Anxiety among the College going Adolescent Boys and Girls

Table 4.7, Level of Frustration among the College going Adolescents Boys

\begin{tabular}{|l|l|l|l|}
\hline Sl. No. & Level of Frustration & Number of Adolescent & Percentage \\
\hline 1 & High (6 and above) & 14 & $13.08 \%$ \\
\hline 2 & Moderate (3-5 Scores) & 29 & $27.11 \%$ \\
\hline 3 & Low (0-2 scores) & 64 & $59.81 \%$ \\
\hline Total & 107 & $100 \%$ \\
\hline
\end{tabular}

Table 4.8, Level of Frustration among the College going Adolescent Girls

\begin{tabular}{|l|l|l|l|}
\hline Sl. No. & Level of Frustration & Number of Adolescent & Percentage \\
\hline 1 & High (7 and above) & 4 & $3.74 \%$ \\
\hline 2 & Moderate (3-6 Scores) & 40 & $37.38 \%$ \\
\hline 3 & Low (0-2 scores) & 63 & $58.88 \%$ \\
\hline Total & 107 & $100 \%$ \\
\hline
\end{tabular}

Regarding Frustration the Table 4.7 and Table 4.8 shows that $59.81 \%, 27.11 \%$ and $13.08 \%$ adolescent boys have Low, Moderate and High level of frustration. Again 58.88\%, 37.38\% and 3.74\% adolescent girls have Low, Moderate and High level of frustration.

(c) The International Journal of Indian Psychology, ISSN 2348-5396 (e)| ISSN: 2349-3429 (p) | 202 
The graphical representation of the above data has shown as follows-

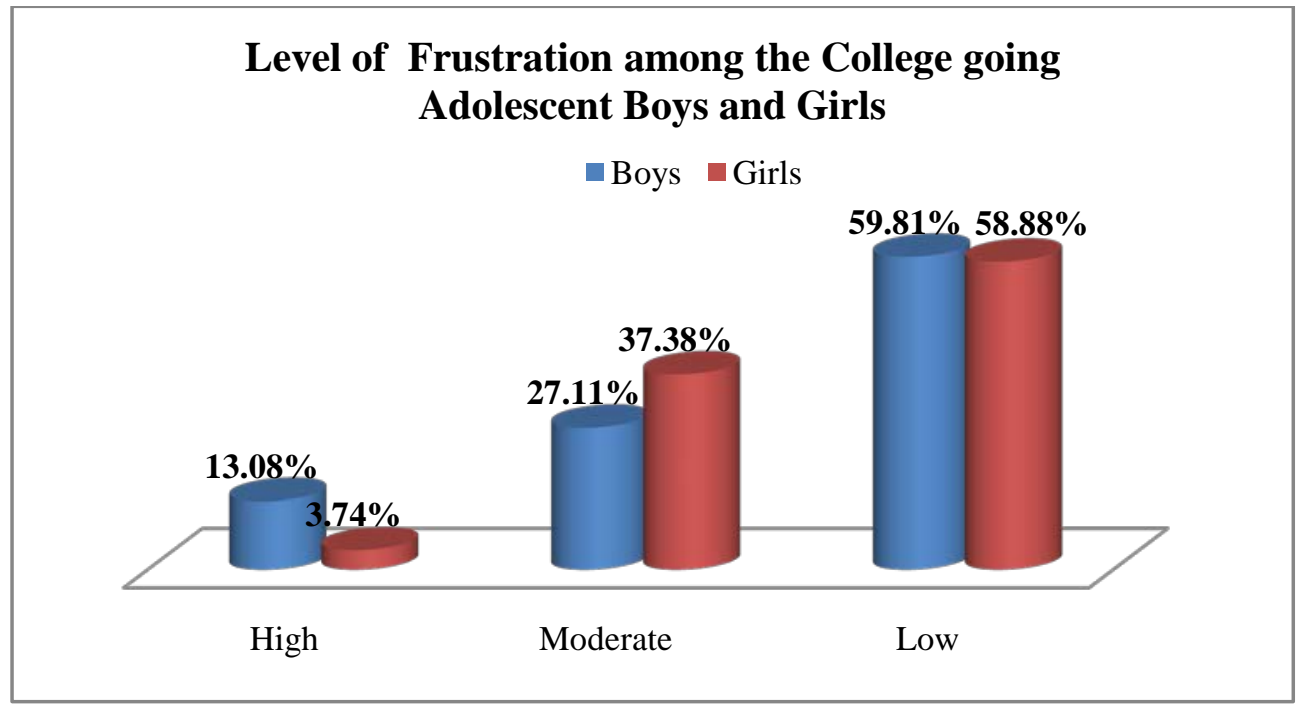

Figure 4.4- Level of Frustration among the College going Adolescent Boys and Girls

\section{OBJECTIVE NO 5}

Table 5.1, Comparative study between the level of stress of College going adolescent boys and girls

\begin{tabular}{|l|l|l|l|l|l|l|}
\hline Sl. No. & Variable & N & Mean & S.D. & t-value & Significance \\
\cline { 1 - 4 } 1 & Boys & 107 & 16.13 & 0.60 & 0.65 & Not \\
\cline { 1 - 4 } & Girls & 107 & 15.60 & 0.56 & & Significant \\
\hline
\end{tabular}

The above Table shows that the boys have mean score 16.13 and the girls have mean score 15.60. The t-value is 0.65 which is found to be not significant at 0.05 and 0.01 level of significance. Therefore, it can be concluded that both adolescent boys and girls have equal level of stress. Hence the null hypothesis- 'There exists no significant difference between the level of stress of the College going adolescents boy and girl living in Guwahati City of Assam.' is accepted.

\section{FINDINGS OF THE STUDY}

The findings of the study are as follows:-

- The study reveals that most of the College going adolescents that are $66.35 \%$ have moderate level of stress. Only a small number that is $2.81 \%$ have high level of stress.

- It is found from the study that most of the College going adolescents that are $65.42 \%$ and $61.68 \%$ has moderate level of Pressure and Anxiety.

- It is interesting to find that almost equal number of College going adolescents have high, moderate and low level of Physical Stress. 31.30\%, 33.65\% and 35.05\%, College going adolescents have high, moderate and low level of Physical Stress respectively. This should be

(c) The International Journal of Indian Psychology, ISSN 2348-5396 (e)| ISSN: 2349-3429 (p) | 203 
given due consideration that 31.03\% College going adolescents have high level of Physical Stress.

- The study reveals that most of the College going adolescents that are $59.81 \%$ have low level of frustration.

- The study shows that both the College going adolescent boys and girls in the age group of $19-22$ years have moderate level of stress which is $67.29 \%$ and $52.33 \%$ respectively.

- Regarding Pressure, it has been found that the level of stress is high (50.46\%) among boys and on the contrary the level of stress is moderate (59.81\%) among girls.

- Regarding Physical Stress, 34.57\%, 31.78\% and 33.65\% College going adolescent boys have high, moderate and low level of Physical Stress. On the other hand, 28.03\%, 35.52\% and 36.45\% College going adolescent girls have high, moderate and low level of Physical Stress. This shows that both boys and girls have almost equal level of Physical Stress.

- It is found from the study that regarding Anxiety, the level of stress is high $(41.12 \%)$ among boys and on the contrary the level of stress is moderate (50.47\%) among girls.

- It is found that both boys and girls in the age group of 19-22 years have low level of frustration which is $59.81 \%$ and $58.88 \%$ respectively.

- The study reveals that there exists no significant difference between the level of stress of College going adolescent boys and girls living in Guwahati City of Assam.

\section{SUGGESTIONS OF THE STUDY}

In the period of modernization, stress has become an everyday life affair for all ages of people. Among the various stages of an individual life, adolescence is a period of change in attitude and behaviour, develops heightened emotionality, outlook, interests pattern and roles. This period is regarded as the period of "storm and stress". The adolescents are very often confronted with stress in their day to day life. It may be due to self, career, academics or other issues, the adolescents undergo anxiety, physical stress, aggression, undesirable complexes and depression. Stress is the key factor affecting the mental health of adolescents. Therefore it is necessary to reduce the level of stress among adolescents. Some of the suggestions that can be put forwarded in this regard are like:-

- The home environment should be congenial and positive so that the feeling of love and affection prevails between parents and children. The adolescents should feel free to discuss and share personal problems with their parents. This will help the adolescents to make healthy adjustment in their life.

- Educational institution is said to be the second home as adolescents spend most of their time. So it is of utmost important that the educational institution should provide all that is required for the student to carry their work and responsibilities in a stress free way.

- Adolescence is a period in which, adolescents are greatly under peer pressure. They are largely influence by peers. Therefore, the parents and teachers have to play an important role in the formation of favourable peer group by acting as a guiding agent.

- The environment in which the adolescents spend should be congenial and friendly for the adolescents, so that they can find ample scope for developing their potentialities and 
inculcating moral values in them. This will also help them to mould their instinctive tendencies in a productive way.

- Last, but not the least, the teacher should be a friend, philosopher and guide for the students. These will help in developing a good inter personal relationship between students and teachers. A favourable relationship between teacher and student will go a long way in providing necessary guidance and support to face various challenges of life.

\section{CONCLUSION}

Stress has become a major concern for the educationist, psychologist and social thinkers. Stress is considered as the key factor affecting the mental health and high level of stress is associated with depression and suicidal attempts. Adolescence is a crucial period of one's life and adolescents are likely to confront with stress in various issues related to physical changes, emotional problems, identity crisis, role and leadership. This may lead them to depression, frustration and various other psychological problems. The school and home have to come forward to fight to the problem of stress among the adolescents. Thus further research and investigation are to be made in various aspects of stress, its causes, consequences and ways to overcome stress both in micro and macro level.

\section{Acknowledgments}

The author appreciates all those who participated in the study and helped to facilitate the research process.

\section{REFERENCES}

Devi, T. U. (2011).A Study on Stress Management and Coping Strategies with reference to IT Companies. Journal of Information Technology and Economic Development. 2(2), 30-48

Hurlock, E.B.(2012)Developmental Psychology A Life -Span Approach. Tata McGraw Hill Education Private Limited, New Delhi.

Hussain, H. (2010). A Study of Teacher Stress: Exploring Practitioner Research and Teacher Collaboration as A way Forward. (PhD Thesis, Bournemouth University)

Koul. L 2013 Methodology of Educational Research Vikas Publishing House Pvt Ltd New Delhi

Mazumdar, H., Gogoi, D. and Haloi, N. (2012). A Comparative study on Stress and its Contributing factors among the Graduates and Post Graduates Students. Advances in Applied Science Research, 3(1) 399-406

Wen, C.K, A Study of Stress sources among college students in Taiwan. Journal of Academic and Business Ethics.

How to cite this article: S Sharma (2016), The Level of Stress among the College going Adolescents Living in Guwahati City of Assam, International Journal of Indian Psychology, Volume 3, Issue 4, No. 63, ISSN 2348-5396 (e), ISSN: 2349-3429 (p), DIP: 18.01.114/20160304, ISBN: 978-1-365-32518-2 